\title{
Phase Composition of Austenitic Stainless Steels in Additive Manufacturing: A Review
}

\author{
Sergey Astafurov (D) and Elena Astafurova *(D) \\ Laboratory of Physics of Hierarchical Structures in Metals and Alloy, Institute of Strength Physics and Materials \\ Science SB RAS, 634055 Tomsk, Russia; svastafurov@gmail.com \\ * Correspondence: elena.g.astafurova@ispms.ru
}

Citation: Astafurov, S.; Astafurova

E. Phase Composition of Austenitic Stainless Steels in Additive

Manufacturing: A Review. Metals 2021, 11, 1052. https://doi.org/ $10.3390 /$ met11071052

Academic Editor: Antonio Mateo

Received: 20 May 2021

Accepted: 28 June 2021

Published: 30 June 2021

Publisher's Note: MDPI stays neutral with regard to jurisdictional claims in published maps and institutional affiliations.

Copyright: (c) 2021 by the authors. Licensee MDPI, Basel, Switzerland. This article is an open access article distributed under the terms and conditions of the Creative Commons Attribution (CC BY) license (https:/ / creativecommons.org/licenses/by/ $4.0 /)$.

\begin{abstract}
Additive manufacturing (AM) is among the novel industrial technologies for fast prototyping of complex parts made from different constructional and functional materials. This review is focused on phase composition of additively manufactured chromium-nickel austenitic stainless steels. Being produced by conventional methods, they typically have single-phase austenitic structure, but phase composition of the steels could vary in AM. Comprehensive analysis of recent studies shows that, depending on AM technique, chemical composition, and AM process parameters, additively manufactured austenitic stainless steels could be characterized by both single-phase austenitic and multiphase structures (austenite, ferrite, $\sigma$-phase, and segregations of alloying elements). Presence of ferrite and other phases in AM steels strongly influences their properties, in particular, could increase strength characteristics and decrease ductility and corrosion resistance of the steels. Data in review give a state-of-art in mutual connection of AM method, chemical composition of raw material, and resultant phase composition of AM-fabricated Cr-Ni steels of 300-series. The possible directions for future investigations are discussed as well.
\end{abstract}

Keywords: additive manufacturing; austenitic stainless steels; phase composition; austenite; ferrite; mechanical properties

\section{Introduction}

Additive manufacturing (AM) or 3D printing is a novel and fast developing technique of rapid layer-by-layer manufacture of prototypes or parts according to computer-aided design (CAD) model. Development of AM has begun with technologies of 3D printing of polymer materials [1]. Progress in this field has given a motivation for the fabrication of complex metal parts using AM methods for the purposes of different industries, such as aerospace, automotive, medical implants production, etc. [1-3]. An indisputable advantage of 3D printing is the ability of fast prototyping and production of parts with complex shapes and different scales in fully automatic mode using CAD models, and with the emphasis to those materials, which are difficult, expensive and/or even cannot be produced by conventional methods [1-5]. Thus, AM is time-, energy-, and material-saving technology.

The keystone problem of AM for metals is that phase composition and mechanical properties of the additively produced materials differ (sometimes extremely) from their conventionally produced counterparts $[1,2,4]$. Here are some unfavorable factors typical of AM materials: a porosity, an anisotropy of mechanical properties, residual stresses, inhomogeneity of grain structure, and texture [1,2,4-7]. But relative to the AM-produced pure metals, one more adverse point is typical of alloys - the difference in chemical compositions of the raw material and the resultant $3 \mathrm{D}$ printed part $[7,8]$.

Chromium-nickel austenitic stainless steels of 300-series are, obviously, one of the most widely used structural materials in the world due to their good ductility, weldability, and high corrosion resistance $[9,10]$. Among the variety of the materials used in AM, these steels take one of the leading positions $[2,4]$, but scientists and manufacturers still face some 
problems during their AM-fabrication. The goal in AM-producing of chromium-nickel steels is obtaining of near single-phase austenitic structure. In reality, the anisotropic multiphase structure forms in $\mathrm{CrNi}$ austenitic stainless due to the complex thermal history and nonequilibrium crystallization conditions during the AM process. This affects exploitation characteristics of AM parts.

This review is focused on the phase composition of additively manufactured chromiumnickel austenitic stainless steels produced by different AM techniques, the correlation of the microstructure and mechanical properties of the AM-fabricated steels, and on analysis of problems and ways for future investigations in this research field.

\section{Methods of Additive Manufacturing of Steels}

Technologies of metal 3D-printing are based on melting and solidification or sintering of feedstock raw material (wire, sheets, or powder) by different sources of energy (laser, plasma, and electric arc or electron beam). According to ASTM Standard [2] there are two basic 3D printing technologies: powder bed systems (PBS) and directed energy deposition (DED). The first one is based on layer-by-layer spreading of thin layers of powder on the operation area with its subsequent melting or fusion in inert gas or vacuum chamber by source power according to CAD model $[2,4,6,11,12]$. In DED processes, the raw material (powder of wire) feeds to the operation area with its simultaneous melting with energy source and layer-by-layer formation of a target product according to a computer model $[1,2,4,6]$.

Relative to the AM production of the steel parts, both DED and PBS methods attract much attention of the scientists. Selective laser melting (SLM) is the PBS method widely used for steel fabrication [12-15]. A powder feed laser melting or laser melting deposition [13,16-21], wire feed laser melting deposition [22], wire and arc additive manufacturing (gas tungsten arc welding (GTAW), gas metal arc welding (GMAW), cold metal transfer (CMT), and plasma arc welding (PAW)) [23-28], wire feed electron-beam melting $[7,8,29,30]$ should be mentioned among the widespread DED AM techniques, which are effectively used for fabrication of austenitic stainless steels of the 300-series. Even so, there is no universal AM method which covers all industrial needs. From the point of view of steel parts production, PBS methods look attractive due to high-resolution features of the complex parts and accurate dimensional control. Some disadvantages of PBS methods should also be mentioned: a relatively small build volume and slow deposition rate, and the need to use high-quality expensive lasers and powders [2,4,31]. Contrarily, high deposition rates (especially in the case of wire-feed systems) and the ability to produce large, full-scale components are the main advantages of the DED methods, but as-built parts often require expensive finishing operations, such as machining and heat treatments, to achieve the desired quality [2].

Indeed, AM production of the austenitic stainless steels covers many AM techniques, and, despite the differences in building methods, the common problems of the directional solidification of the austenitic grains and undesirable phase composition exist in steel products.

\section{Solidification Mechanisms in AM Austenitic Steels}

Austenitic stainless steels of 300-series are Fe-based alloys containing chromium and nickel as the basic alloying elements. Steel composition should provide fully austenitic structure, but in conventional production it is achieved by a final solid-solution treatment $[9,10]$. Resultant phase composition and phase morphology depends on the ratio of chromium $\left(\mathrm{Cr}_{\mathrm{eq}}\right)$ and nickel $\left(\mathrm{Ni}_{\mathrm{eq}}\right)$ equivalents [32-36]:

$$
\begin{aligned}
& \mathrm{Cr}_{\text {eq }}=w t . \% \mathrm{Cr}+\text { wt. } \% \mathrm{Mo}+1.5 w t . \% \mathrm{Si}+0.5 w t . \% \mathrm{Nb} \\
& \mathrm{Ni}_{\text {eq }}=\text { wt. } \% \mathrm{Ni}+0.5 w t . \% \mathrm{Mn}+30 \mathrm{wt} . \% \mathrm{C}+30 \mathrm{wt} . \% \mathrm{~N} .
\end{aligned}
$$


According to the Schaeffler diagram, the solidification mode, phase transformation, and final phase composition all depend on the $\mathrm{Cr}_{\text {eq }} / \mathrm{Ni}_{\text {eq }}$ ratio [32-36]:

$$
\begin{gathered}
\text { A mode }\left(\mathrm{Cr}_{\mathrm{eq}} / \mathrm{Ni}_{\mathrm{eq}}<1.25\right): \mathrm{L} \rightarrow(\mathrm{L}+\gamma) \rightarrow \gamma \\
\text { AF mode }\left(1.25<\mathrm{Cr}_{\mathrm{eq}} / \mathrm{Ni}_{\mathrm{eq}}<1.48\right): \mathrm{L} \rightarrow(\mathrm{L}+\gamma) \rightarrow(\mathrm{L}+\gamma+\delta) \rightarrow(\gamma+\delta) \\
\text { FA mode }\left(1.48<\mathrm{Cr}_{\mathrm{eq}} / \mathrm{Ni}_{\mathrm{eq}}<1.95\right): \mathrm{L} \rightarrow(\mathrm{L}+\delta) \rightarrow(\mathrm{L}+\delta+\gamma) \rightarrow(\delta+\gamma) \\
\text { F mode }\left(\mathrm{Cr}_{\mathrm{eq}} / \mathrm{Ni}_{\mathrm{eq}}>1.95\right): \mathrm{L} \rightarrow(\mathrm{L}+\delta) \rightarrow \delta+\gamma
\end{gathered}
$$

Thus, in the AM process, fully austenitic structure could be reached only for steels with $\mathrm{Cr}_{\mathrm{eq}} / \mathrm{Ni}_{\mathrm{eq}}<1.25$ in the melting pool (A mode). In all other solidification modes (AF, FA, and F modes), two phases are formed. The presence of austenitic $\gamma$-phase in the case of ferrite solidification mode (F mode) is associated with peritectic solid-state transformation of $\delta$-ferrite during cooling. Most compositions of 300-series commercial austenitic stainless steel promote AF or FA solidification modes. So, formation of ferritic phase during solidification is inevitable.

In practice, morphology and volume content of $\delta$-phase are determined not only by $\mathrm{Cr}_{\mathrm{eq}} / \mathrm{Ni}_{\mathrm{eq}}$ ratio in the raw material but also with the parameters of the manufacturing method, cooling rates, etc. [5].

\section{Phase Composition and Mechanical Properties of AM Austenitic Stainless Steels 4.1. AISI 304 and AISI 308-Type Stainless Steels}

High strength characteristics and ductility, weldability, corrosion resistance (due to high chromium content), and relatively low cost make AISI 304 and AISI 304L austenitic stainless steels attractive for different applications in petroleum, nuclear, and chemical industries $[37,38]$. Deformation-induced martensitic transformation from austenite to bccmartensite ( $\alpha^{\prime}$ phase) contributes high strain hardening of these grades of steel [39-42]. AISI 308L steel contains higher chromium and nickel and lower carbon concentrations than AISI 304L steel, but it also has high strength properties and high corrosion resistance [43]. It is used in gas, oil manufacturing and mining, steamship building, and automobile industries. Therefore, this group of CrNi austenitic stainless steels is of interest for AM production.

Table 1 contains data about concentration of the main alloying elements influencing $\mathrm{Cr}_{\text {eq }} / \mathrm{Ni}_{\text {eq }}$ ratio for AISI $304,304 \mathrm{~L}$, and $308 \mathrm{~L}$ steels used for additive manufacturing and described in recent articles. The compositions given by AISI standard are also presented in Table 1. Values of $\mathrm{Cr}_{\text {eq }} / \mathrm{Ni}_{\text {eq }}$ ratio for this group of AISI 304/308 steels are near the upper border of $\mathrm{AF}$ or in the range of FA solidification mode $\left(\mathrm{Cr}_{\mathrm{eq}} / \mathrm{Ni}_{\mathrm{eq}} \approx 1.4-1.8\right)$. Accordingly, solidification process develops according to schemes (4) and (5). Austenitic dendrites should form from the melt at the early stages of solidification with subsequent ferrite formation in the interdendritic regions between austenite dendrites in the case of AF mode, and reverse sequence should be realized in FA mode [32-36]. In any case, a two-phase $(\gamma+\delta)$ microstructure is expected in AISI 304/308 steels in AM production considering the $\mathrm{Cr}_{\mathrm{eq}} / \mathrm{Ni}_{\mathrm{eq}}$ ratio. But further analysis of the articles in the field shows that processing parameters could influence phase ratio and their morphology.

Tarasov et al. [8,44] used AISI 304 wire with the chemical composition of Fe-18.4Cr9.5Ni-1.4Mn-0.8Si-0.12C (wt.\%) for wire-feed electron beam additive manufacturing (EBAM) of the billets $\left(\mathrm{Cr}_{\mathrm{eq}} / \mathrm{Ni}_{\mathrm{eq}}=1.42\right)$. EBAM-fabricated specimens were characterized by primarily austenitic structure with thin ferrite crystallites between austenitic dendrites. Ferrite colonies had different morphology — vermiculate, cellular, lathy, or point-like. Despite the fact that wire composition did not change in the AM process, the volume content of $\delta$-ferrite depended on the heat input value during the AM process (Figure 1) [8]. Increase in heat input up to some threshold value led to increase in ferrite fraction from 13 up to $19 \mathrm{vol} . \%$ with following decrease in volume content of $\delta$-phase down to $14 \mathrm{vol} . \%$ at high heat input values. The authors propose that chromium atoms, which are ferrite stabilizers, are forced out to the interdendritic regions during austenitic dendrite growth. Increase in 
heat input up to threshold value promotes this process and assists the increase in volume content of $\delta$-phase. Further increase in heat input higher than the threshold value facilitates the reheating of deposited metal and partial ferrite dissolution (decrease in volume content of $\delta$-phase). The ratio of austenitic/ferritic phases influences mechanical properties of the AM-fabricated steel. Increase in volume content of ferrite leads to strengthening, decrease ductility, and corrosion resistance of the steels [44]. Thus, the authors [8,44] concluded that one can partially control the volume content of ferrite by variation of heat input value.

Table 1. Chemical compositions (wt. $\%$, Fe balanced) and corresponding values of $\mathrm{Cr}_{\mathrm{eq}} / \mathrm{Ni}_{\mathrm{eq}}$ ratio for AISI 304 and 308 type austenitic stainless steels used for AM. AF-austenite-ferrite solidification mode, FA-ferrite-austenite solidification mode, F-ferrite solidification mode. Data are adapted from $[8,12,16,18,22,25,43-46]$.

\begin{tabular}{|c|c|c|c|c|c|c|c|c|}
\hline Ref. & $\mathrm{Cr}$ & $\mathrm{Ni}$ & Mn & Si & Mo & $\mathbf{N}$ & $\mathrm{C}$ & $\begin{array}{c}\mathrm{Cr}_{\mathrm{eq}} / \mathrm{Ni}_{\mathrm{eq}} \\
\text { Solidification Mode }\end{array}$ \\
\hline \multicolumn{9}{|c|}{ AISI 304} \\
\hline Standard & $18-20$ & 8-11 & $\leq 2$ & $\leq 1$ & - & $\leq 0.1$ & $\leq 0.08$ & - \\
\hline$[8,44]$ & 18.4 & 9.5 & $\overline{1.4}$ & $\overline{0.8}$ & - & - & 0.12 & $1.42, \mathrm{AF}$ \\
\hline \multicolumn{9}{|c|}{ AISI 304L } \\
\hline Standard & $18-20$ & 8-12 & $\leq 2$ & $\leq 1$ & - & $\leq 0.1$ & $\leq 0.03$ & - \\
\hline [18] & 19.1 & 10.4 & $\overline{1.6}$ & $\overline{0.5}$ & 0.04 & $\overline{0.089}$ & $\overline{0} .015$ & $1.39, \mathrm{AF}$ \\
\hline$[12,45]$ & 18.9 & 9.48 & 0.016 & 0.056 & 0.87 & 0.013 & 0.006 & $1.94, \mathrm{FA}$ \\
\hline [16] & 19.0 & 10.3 & 1.5 & 0.5 & 0.04 & 0.08 & 0.01 & $1.44, \mathrm{AF}$ \\
\hline \multicolumn{9}{|c|}{ AISI 308L } \\
\hline Standard & $19-21$ & $10-12$ & $1-2.5$ & $0.3-0.6$ & - & - & $\leq 0.03$ & - \\
\hline [22] & 19.5 & 10.5 & 1.9 & 0.85 & - & - & 0.01 & $1.77, \mathrm{FA}$ \\
\hline [43] & 19.86 & 9.84 & 1.7 & 0.48 & 0.0096 & - & 0.021 & $1.82, \mathrm{FA}$ \\
\hline [25] & 20.23 & 9.52 & 2.11 & 0.56 & - & 0.035 & 0.03 & $1.68, \mathrm{FA}$ \\
\hline [46] & 20.71 & 9.54 & 2.15 & 0.82 & - & - & 0.017 & $1.97, \mathrm{~F}$ \\
\hline
\end{tabular}
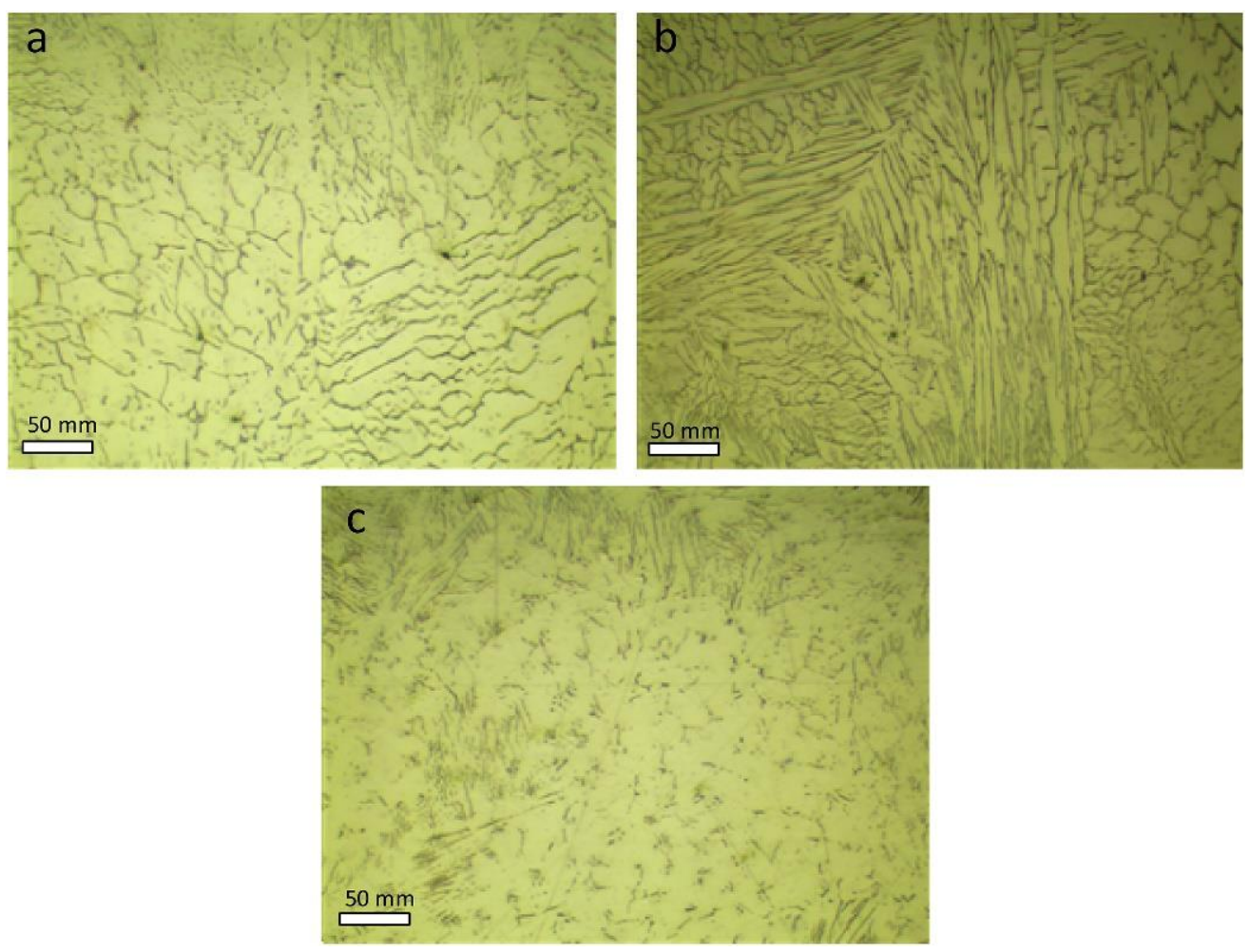

Figure 1. Optical images of the etched austenite + vermicular ferrite microstructure images of AM samples of the AISI 304 steel grown at heat input values (a) 0.22 , (b) 0.25 , and (c) $0.27 \mathrm{~kJ} / \mathrm{mm}$ as viewed along the build-up direction. Reprinted with permission from [8], Copyright 2019 Elsevier. 
Wire-feed electron beam AM was used for producing the walls of AISI 304 steel (Fe-19.1Cr-9.1Ni-0.95Si-0.12C, wt.\%) in series of the recent articles [7,29,30,47,48]. During EBAM processing, solidification was realized in FA mode $\left(\mathrm{Cr}_{\mathrm{eq}} / \mathrm{Ni}_{\mathrm{eq}}=1.7\right)$. Obtained samples had austenitic structure with colonies of ferritic dendrites (vermicular and lathy), and $\delta$-ferrite phase was enriched with chromium and depleted by nickel (Figure 2). The authors reported the gradual increase in $\delta$-ferrite content moving along the AM-building direction, starting near the substrate and finishing in the top part of the AM-fabricated wall. Volume content of ferrite depends on cooling rate and $\mathrm{Cr}_{\mathrm{eq}} / \mathrm{Ni}_{\mathrm{eq}}$ value. Cooling rate gradually decreases during wall growth, and the increase in ferrite content in the top part of the wall is associated with the depletion of the melt by nickel and increase in $\mathrm{Cr}_{\mathrm{eq}} / \mathrm{Ni}_{\mathrm{eq}}$ ratio. Obtained billets possessed high anisotropy of mechanical properties due to revealed structural inhomogeneity in $\delta$-ferrite fraction and columnar grain structure of austenite. One-hour solid-solution treatment at the temperature $1050{ }^{\circ} \mathrm{C}$ caused a twofold decrease in volume content of ferritic phase but did not eliminate it.
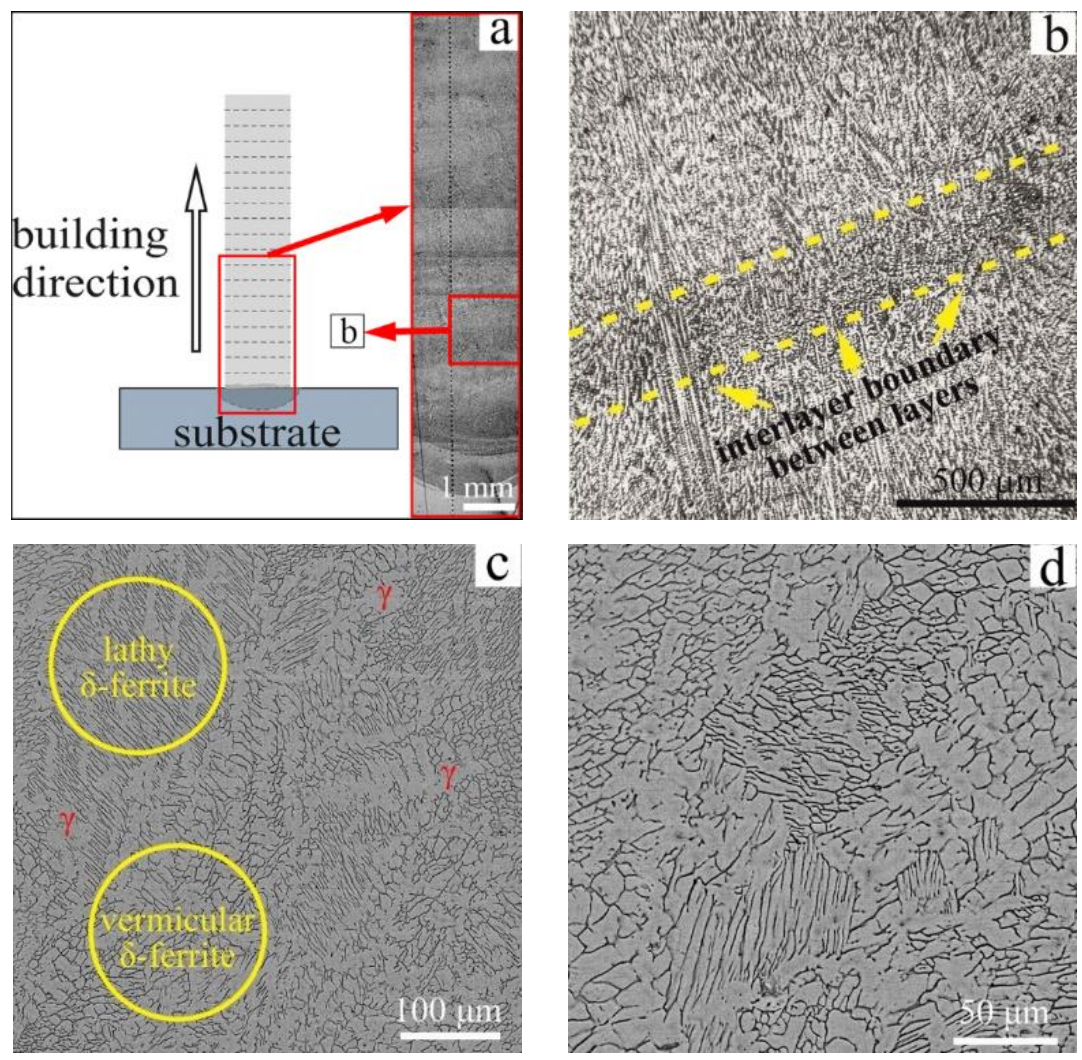

Figure 2. Light microscopy images $(\mathbf{a}, \mathbf{b})$ and scanning electron microscopy backscattered electron images $(\mathbf{c}, \mathbf{d})$ of as-built specimens. All images correspond to a cross-sectional surface along the building direction and transverse to the layers. Reprinted with permission from [7], Copyright 2020 Springer Nature.

Using selective laser-beam melting (SLM) AM technology and gas-atomized powders of AISI 304L steel (Fe-18.95Cr-9.48Ni-0.87Mo-0.056Si-0.033Cu-0.029O-0.027P-0.016Mn$0.013 \mathrm{~N}-0.01 \mathrm{Co}-0.006 \mathrm{C}-0.001 \mathrm{~S}$, wt.\%) $\left(\mathrm{Cr}_{\mathrm{eq}} / \mathrm{Ni}_{\mathrm{eq}}=1.94\right)$ as the raw material, steel billets with a relative density of $99.9 \%$ were produced [12,45]. SLM-fabricated steel had primarily austenitic structure with columnar and dendritic austenitic grains, consisting of subgrains (cells). The authors attribute such cellular fine structure to the high thermal gradient along building direction and high cooling rate during solidification. The SLM-produced structure also contained about 4 vol. $\%$ of small (up to several micrometers) $\delta$-ferrite grains, randomly distributed in the bulk material, and about 0.4 vol.\% of nanosized particles of $\sigma$-phase located along high-angle grain boundaries (Figure 3) [12]. Blocky ferrite for- 
mation is attributed to the extremely high cooling rate during the SLM process (higher than $3 \times 10^{4} \mathrm{~K} \mathrm{~s}^{-1}$ [49]), while $\sigma$-phase (CrFeMo-based particles) arises due to reheating of the material during the building process. For SLM manufacturing of the steels, the post-built solid solution treatment allows the dissolution of ferritic phase completely [45]. Moreover, $\mathrm{H}$. Yu et al. [11] has obtained fully austenitic structure in AISI 304 steel billets using SLM AM without any post-building treatments. The authors have not provided the chemical composition of AISI 304 powder, which they have used for AM, and fully austenitic structure in SLM-fabricated steel billet can be associated with reduced $\mathrm{Cr}$ and high $\mathrm{Ni}$ and $\mathrm{C}$ content in the raw material, which decrease the $\mathrm{Cr}_{\mathrm{eq}} / \mathrm{Ni}_{\mathrm{eq}}$ ratio.

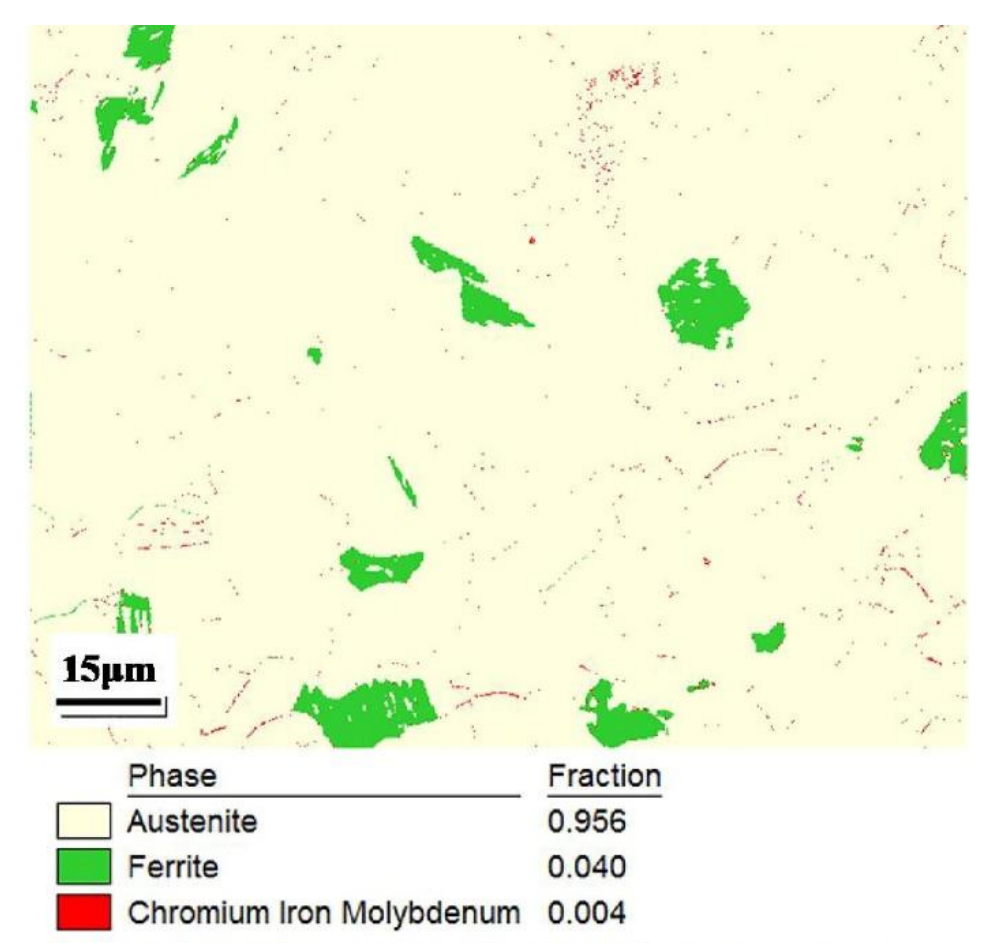

Figure 3. EBSD results of phase distribution map with the ferrite in green, $\sigma$ phase in red, and austenite matrix in canary as shown by the color coding. Reprinted with permission from [12], Copyright 2020 Elsevier.

In articles [17,50], Brown et al. used powder-feed laser-based DED or laser melting deposition (LMD) technologies for fabrication AISI 304L steel billets. Powder chemical composition was typical of AISI 304L steel (Fe-19.07Cr-10.38Ni-1.55Mn-0.5Si-0.089N-0.04Mo$0.03 \mathrm{Cu}-0.02 \mathrm{~V}-0.017 \mathrm{O}-0.015 \mathrm{C}-0.006 \mathrm{P}-0.006 \mathrm{~S}, \mathrm{wt} . \%)\left(\mathrm{Cr}_{\mathrm{eq}} / \mathrm{Ni}_{\mathrm{eq}}=1.44\right)$. Obtained billets were characterized by grain/subgrain austenitic structure with about 2 vol. $\%$ of fine ferritic phase in austenite subgrain boundaries. A similar result was obtained in other research papers $[13,16,18]$, where authors used the same AM technology and steel compositions as in the research of Brown et al. $[17,50]$. Therefore, austenitic structure with columnar grains of austenite with 1.5-2 vol.\% of ferritic phase is the common characteristic of the LMD AM steel. Post-built heat treatments in a temperature range of $1000-1250{ }^{\circ} \mathrm{C}$ caused the decrease in dislocation density and complete dissolution of ferrite [50].

Wire-feed LMD AM was used for producing AISI 308LSi steel billets in [22]. Authors obtained austenitic billet with about $4-5 \%$ of ferrite (according to the analysis of scanning electron microscopy images, see Figure 4 [22]). $\mathrm{The}_{\mathrm{Cr}} / \mathrm{Ni}_{\mathrm{eq}}=1.77$ ratio for wire composition Fe-19.5Cr-10.5Ni-1.9Mn-0.85Si-0.02P-0.02S-0.01C (wt.\%) provides FA solidification mode with the first formation of ferrite, followed by austenite formation in the interdendritic regions and the substitution of ferrite in the austenitic phase. 


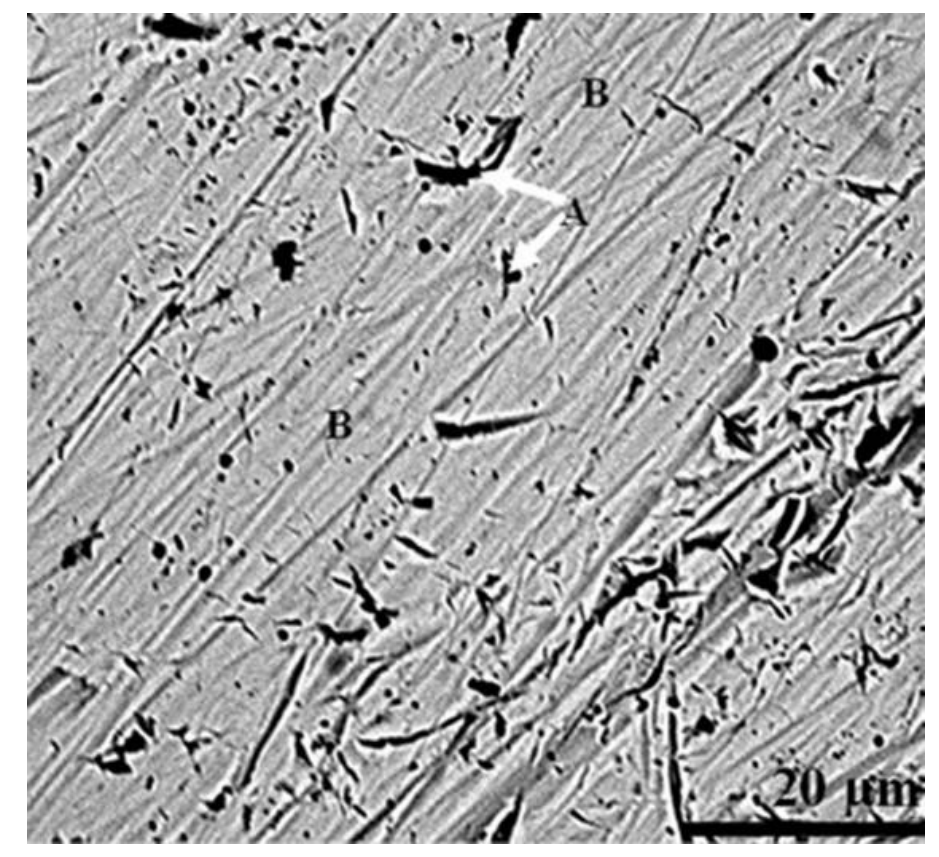

Figure 4. Scanning electron microscopy/back scattered electron image of the core region of the cross-sectioned single laser track of AISI 308LSi. A-ferrite, B-austenite. Reprinted with permission from [22], Copyright 2017 Taylor and Francis.

Similar two-phase structures were obtained using arc additive manufacturing technique (WAAM). Gordon et al. [23] used WAAM for producing AISI 304L billets with ferrite number 10 and skeletal and lathy $\delta$-ferrite morphologies. Li et al. [25] also used WAAM technology for producing billets of AISI 308L austenitic stainless steel. A small amount of ferritic phase was uniformly distributed in austenitic matrix of the AM billets, and the volume content of ferrite increased with the distance from the substrate from 2.9 up to 3.8 vol.\% (Figure 5). The morphology of ferritic phase depends on the distance from the supporting plate. The bottom layers contain mainly lathy and granular ferrite, $\delta$-phase has predominantly skeletal morphology in the top region, and all three morphological types of ferrite are observed in the middle part of the billet. The main factor promoting such variation in ferrite morphology is the change in cooling rate with the distance from supporting plate in WAAM process. Solidification of AISI 308L steel develops in FA mode with primary ferrite formation and following replacement of the ferrite by austenitic phase during crystallization [24,43]. As a result, columnar dendritic austenitic structure is formed with the residual ferrite of skeletal, lathy, and vermicular morphology.

Miao Li et al. [46] used wire-feed laminar plasma AM for producing AISI 308L steel billets. Argon gas was used for plasma forming and as a shielding gas during the AM process. The authors obtained steel billets with fully austenitic structure (Figure 6a) although initial chemical composition of the wire (Fe-20.71Cr-9.54Ni-2.15Mn-0.82Si-0.018P-0.008S$0.017 \mathrm{C}-0.013 \mathrm{Cu}$, wt. $\%$ ) provided rather high value $\mathrm{Cr}_{\mathrm{eq}} / \mathrm{Ni}_{\mathrm{eq}}=1.97$ and $\mathrm{F}$ solidification mode (Table 1).

Except from the intriguing result by Li et al. [46], all mentioned above results demonstrate the common trend in AM fabrication of the AISI 304L/308L steels-austenitic structure with coarse columnar grains contains $\delta$-ferrite, which fraction and morphology can vary in dependence on nominal composition of the raw material, method of AM, and processing regime $[1,2,6-8,12,17,22-24,29,30,43-45,48,50]$. In nonequilibrium conditions and due to the probable change in concentration of ferrite stabilizing elements in the melt (Mo, Cr, $\mathrm{Si}$ ), the solidification of steel with composition corresponded to FA mode (reaction (5) in Section 3) could be realized according to AF mode (reaction (4) in Section 3) and vice versa $[14,48]$. The EBAM method provides the highest $\delta$-ferrite fraction in the AM-steel billets, which usually could not be dissolved using post-built heat treatments. Contrarily, 
the fraction of ferrite in materials produced by SLM, LMD, laser-based DED, and WAAM is much lower and it could be removed by post-processing heat treatments [17].
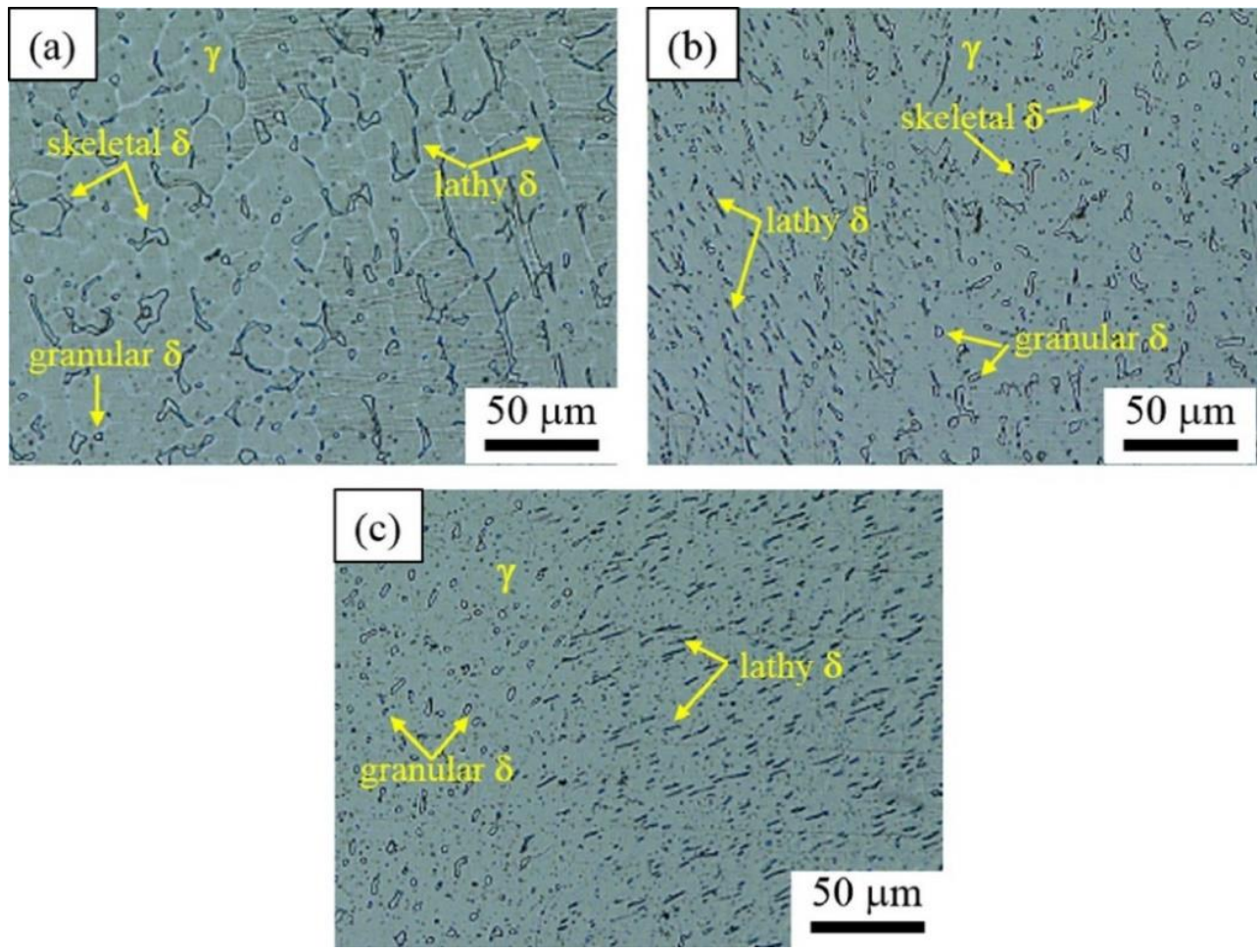

Figure 5. Microstructure of WAAM 308 L stainless steel characterized by optical microscopy at (a) top layer, (b) middle layer, and (c) bottom layer. Reprinted with permission from [25], Copyright 2021 Elsevier.
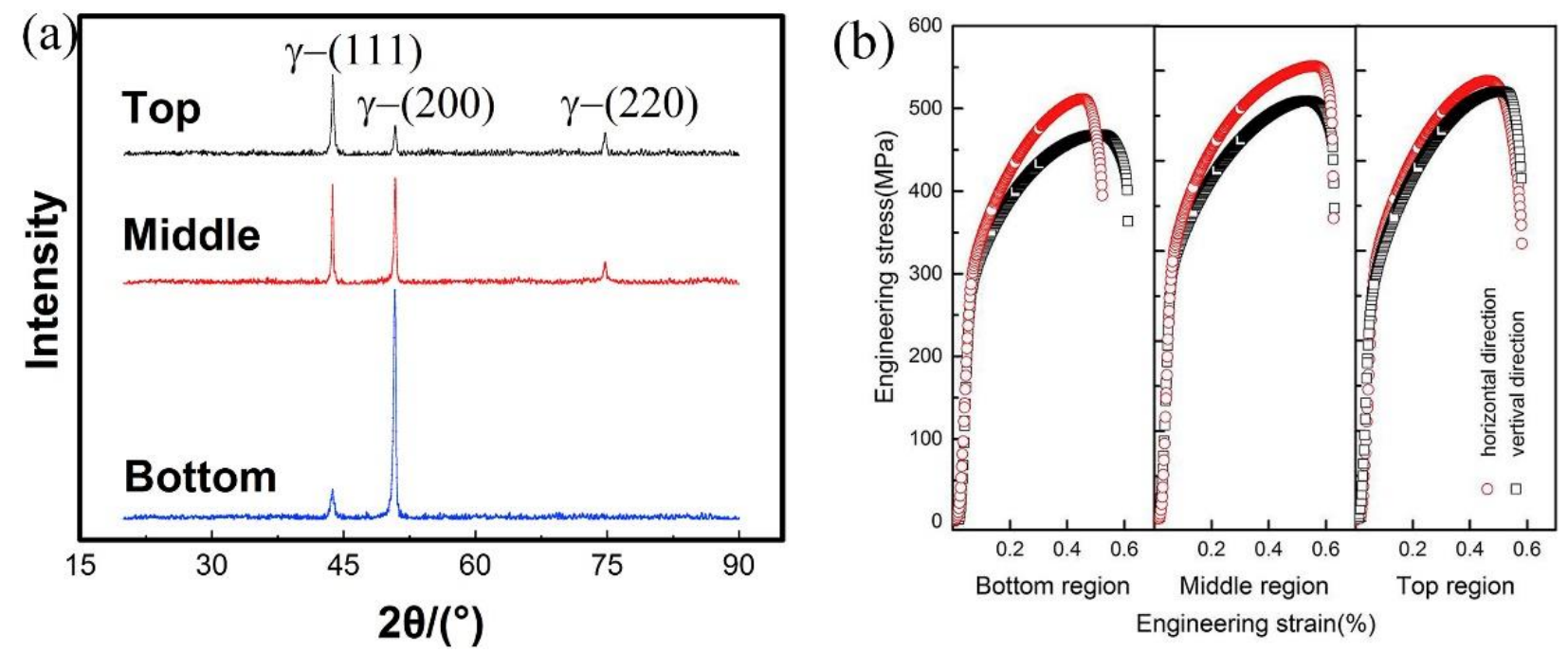

Figure 6. XRD patterns $(\mathrm{Cu}-\mathrm{K} \alpha)$ of samples at (a) different height and curves of engineering stress vs. (b) engineering strain for wire-feed laminar plasma AM AISI308L steel. Reprinted with permission from [46], Copyright 2020 Elsevier.

The comparison of the mechanical properties of the AISI 304/308 SS obtained with different AM methods are summarized in Table 2. Despite the fact that AISI 308L steel billets fabricated in wire-feed laminar plasma AM [46] possess completely austenitic structure, their yield strength is a bit higher but other tensile characteristics are very similar to those for conventionally produced steels (Figure 6b, Table 2). 
Table 2. Comparison of the mechanical properties of AM-fabricated AISI 304/308 stainless steels. The compositions are given in wt.\%. Data are adapted from [7,11,12,25,43,46].

\begin{tabular}{|c|c|c|c|}
\hline Method of Manufacture, Composition & Yield Strength, MPa & Ultimate Tensile Strength, $\mathrm{MPa}$ & Elongation, $\%$ \\
\hline \multicolumn{4}{|c|}{ Conventionally produced AISI 304/308 SS } \\
\hline AISI 304L [12] & 170 & 485 & 40 \\
\hline AISI 308L annealed [25] & 205 & 515 & 30 \\
\hline \multicolumn{4}{|c|}{ AISI $304 / 308$ SS fabricated with AM methods } \\
\hline EBAM, AISI 304 (Fe-19.1Cr-9.1Ni-0.95Si-0.12C) [7] & $252-277$ * & $810-890 *$ & $36-47 *$ \\
\hline $\begin{array}{l}\text { SLM, AISI 304L (Fe-18.95Cr-9.48Ni-0.87Mo-0.056Si-0.033Cu-0.029O-0.027P-0.016Mn- } \\
0.013 \mathrm{~N}-0.01 \mathrm{Co}-0.006 \mathrm{C}-0.001 \mathrm{~S} \text { ) [12] }\end{array}$ & $414-458$ * & $615-655 *$ & $65-71 *$ \\
\hline SLM, AISI 304L [11] & $500-520$ & $750-800$ & $48-52$ \\
\hline $\begin{array}{c}\text { WAAM, AISI308L } \\
\text { (Fe-20.23Cr-9.52Ni-2.11Mn-0.56Si-0.0349N-0.0344O-0.03C-0.014P-0.013S, wt.\%) [25] }\end{array}$ & 269 & 580 & 68 \\
\hline $\begin{array}{l}\text { WAAM, AISI308L } \\
\text { (Fe-19.86Cr-9.84Ni-1.7Mn-0.48Si-0.076Cu-0.028P-0.021C-0.019S-0.0096Mo, wt.\%) [43] }\end{array}$ & $343-352 *$ & $531-552 *$ & $40-54$ * \\
\hline $\begin{array}{l}\text { Wire-feed laminar plasma, AISI308L } \\
\text { (Fe-20.71Cr-9.54Ni-2.15Mn-0.82Si-0.018P-0.008S-0.017C-0.013Cu wt.\%) [46] }\end{array}$ & $287-359$ * & $467-511$ * & $47-58$ * \\
\hline
\end{tabular}

* Intervals indicate the variation of the mechanical properties due to the anisotropy of the microstructure. 
The existence of the small fraction of $\delta$-ferrite in WAAM-produced billets [25] or in EBAM-fabricated ones [7] assists higher tensile strength of the AM-steel relative to those with fully austenitic structures (Table 2). Due to high dislocation density in austenitic grains and fine ferrite, two-phase specimens typically show higher flow stress value (up to $200 \mathrm{MPa}$, see for instance [17]) relative to that of conventionally produced steel. Postbuilt heat treatments in a temperature range of $1000-1250{ }^{\circ} \mathrm{C}$, which is accompanied by the decrease in dislocation density and dissolution of ferrite, causes the decrease in strength (Figure 7) [50]. Under tensile tests of the steel specimens fabricated with WAAM method, plastic deformation starts in the softer austenitic phase and further develops in ferritic one with cracking predominantly in lathy ferrite [25]. During plastic deformation, dendritic $\delta$-ferrite causes hardening effect similar to the grain refinement (Hall-Petch effect) due to the limitation of the dislocation free path between interphase boundaries (austenite/ $\delta$-ferrite) [7]. A columnar austenitic and dendritic structures, typical of AMproduced materials, is the primary reason for anisotropy of the mechanical properties in these specimens (Table 2).

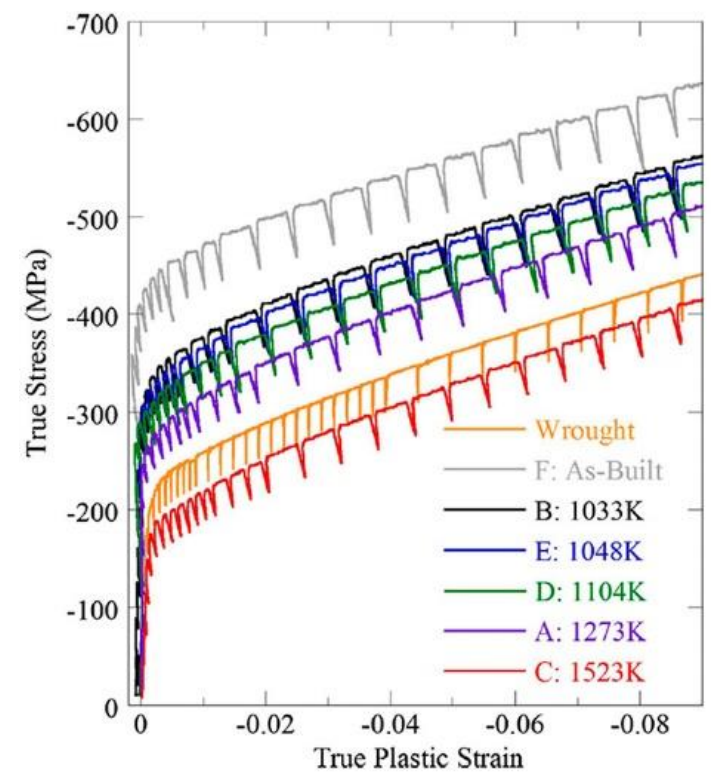

Figure 7. Macroscopic stress/strain curves for AM-fabricated 304L steel in dependence on postbuilt heat treatments. The stress drops are due to relaxation during the neutron diffraction data collection periods which were made in the authors' experiments. Reprinted with permission from [50], Copyright 2019 Springer Nature.

Specimens obtained by the SLM method are characterized by the highest strength characteristics and ductility in comparison with those of cast and wrought AISI 304L steel (Table 2). The enhanced mechanical properties are the result of the synergetic effect of small grain size, the presence of ultra-fine subgrains (Hall-Petch effect), precipitation hardening by ferrite and $\sigma$-phase particles, and high dislocation density in austenitic grains, induced by residual stresses [12].

To conclude, the AM-fabricated AISI 304L/308L steels looks attractive for practical use from the point of view of their mechanical properties in static tensile tests, but further investigation of the corrosion resistance, wear and fatigue properties, deformation behavior, deformation-induced martensitic transformations, etc. are needed.

\subsection{AISI 316L Type Stainless Steels}

AISI 316L type stainless steel is one of the most widely used materials in different industries (medical tools, thermal and nuclear power plants, oil and gas industres, and chemical applications) due to its high ductility and strength characteristics, excellent cor- 
rosion resistance, and relatively low cost [15,51-54]. In contradiction to AISI 304L/308L steels, this steel does not undergo deformation-induced martensitic transformation, which makes it important for applications where nonmagnetic corrosion-resistant steels are required $[9,10]$. These advantages initiate investigations in the field of additive manufacturing of AISI 316L-type austenitic stainless steels. Nevertheless, the chemical compositions of the standard steel and those used for AM-fabrication correspond to AF and FA solidification modes (Table 3). Thus, the ferritic phase is expected in additively manufactured parts (ferrite is a ferromagnetic phase), which eliminates the main advantage of the AISI 316L type stainless steel.

Table 3. Chemical composition (wt.\%, Fe bal.) and corresponding values of Creq/Nieq ratio for some AISI 316L-type austenitic stainless steels used for AM. Data are adapted from $[14,19-21,26,27,51,52,55,56]$.

\begin{tabular}{ccccccccc}
\hline Ref. & $\mathbf{C r}$ & $\mathbf{N i}$ & $\mathbf{M n}$ & $\mathbf{S i}$ & $\mathbf{M o}$ & $\mathbf{N}$ & $\mathbf{C}$ & $\mathbf{C r} \mathbf{r}_{\mathbf{e q}} / \mathbf{N i}_{\mathbf{e q}}$ \\
\hline & & & \multicolumn{7}{c}{ AISI 316L } \\
Standard & $16-18$ & $10-14$ & $\leq 2$ & $\leq 0.75$ & $2-3$ & - & $\leq 0.03$ & - \\
[26] & 18.74 & 11.82 & 1.55 & 0.56 & 2.67 & - & 0.0014 & $1.76 \mathrm{FA}$ \\
{$[55]$} & 18.39 & 12.5 & 1.69 & 0.81 & 2.25 & 0.013 & 0.02 & $1.52 \mathrm{FA}$ \\
{$[19]$} & 17.7 & 12.6 & 0.29 & 0.58 & 2.33 & - & 0.016 & $1.58 \mathrm{FA}$ \\
{$[52]$} & 17.7 & 13.6 & 1.6 & 0.22 & 2.8 & 0.092 & 0.006 & $1.2 \mathrm{AF}$ \\
{$[14]$} & 17.09 & 10.61 & 1.17 & 0.59 & 2.38 & 0.09 & 0.013 & $1.42 \mathrm{AF}$ \\
{$[51]$} & 17 & 10.6 & 0.98 & 0.4 & 2.3 & 0.15 & 0.01 & $1.25 \mathrm{~A}-\mathrm{AF}$ \\
{$[27]$} & 17.09 & 10.61 & 1.17 & 0.59 & 2.38 & 0.09 & 0.013 & $1.42 \mathrm{AF}$ \\
{$[20]$} & 17.4 & 12.4 & 1.5 & 0.53 & 2.5 & 0.06 & 0.02 & $1.33 \mathrm{AF}$ \\
{$[21]$} & 19.95 & 10.87 & 1.41 & 0.61 & 2.45 & - & 0.042 & $1.82 \mathrm{FA}$ \\
{$[56]$} & 17.07 & 12.08 & 1.19 & 0.46 & 2.41 & 0.01 & 0.006 & $1.53 \mathrm{FA}$ \\
\hline
\end{tabular}

To date, different AM methods have been successfully utilized for fabrication of the AISI 316L type stainless steel. Some of them demonstrated that the heterophase structures form in AM production of the type 316 steel, but relative to the 304L/308L steel, a portion of intermetallic $\sigma$-phase often forms additionally to $\delta$-ferrite (due to the increased $\mathrm{Ni}$ and Mo content in the steel composition).

Using WAAM technique, the billets with austenitic structure containing about $4-5 \mathrm{vol} \%$ of ferritic phase have been obtained in different research groups [27,57,58]. Chen et al. [26] used the WAAM method (gas metal arc additive manufacturing-GMA-AM) to produce the billet of AISI 316L steel with the following composition: Fe-18.74Cr-11.82Ni-2.67Mo1.55Mn-0.56Si-0.17Cu-0.03P-0.0014C (wt.\%, $\left.\mathrm{Cr}_{\text {eq }} / \mathrm{Ni}_{\text {eq }}=1.76\right)$. The resulting steel billet was characterized by predominantly austenitic structure, but columnar $\gamma$-phase grains contained ferrite of fine vermicular morphology and $\sigma$-phase along austenite-ferrite boundaries (Figure 8a). The authors did not show the accurate volume content of $\delta$ - and $\sigma$-phases, but according to the microscopic analysis it was about 10 vol.\%. Post-built heat treatment changes volume content of ferritic and intermetallic phases [59]:

- $\quad$ 1-h annealing at the temperature of $1000{ }^{\circ} \mathrm{C}$ increases content of $\sigma$-phase and leads to a spheroidization of ferritic grains (Figure 8a); and

- $\quad 1$-h annealing in the temperature range of $1100-1200{ }^{\circ} \mathrm{C}$ provides a complete dissolution of $\sigma$-phase and decrease in volume content of ferrite.

Despite the variation in $\delta$ - and $\sigma$-phases, heat treatment for $1 \mathrm{~h}$ in the temperature range $1000-1200{ }^{\circ} \mathrm{C}$ does not affect the columnar austenitic grain structure, but $4 \mathrm{~h}$ annealing at a temperature $1200{ }^{\circ} \mathrm{C}$ leads to formation of equiaxed coarse austenitic grain structure with complete dissolution of $\delta$ - and $\sigma$-phases (Figure 8c) [59].

In [21] the authors utilized the direct laser deposition for fabrication of AISI 316L stainless steel. Gas-atomized powder of the following chemical composition was used: Fe-19.95Cr-10.87Ni-2.45Mo-1.41Mn-0.61Si-0.042C-0.025P-0.011S (wt. \%, $\mathrm{Cr}_{\mathrm{eq}} / \mathrm{Ni}_{\mathrm{eq}}=1.82$ ). After AM-building, steel billet has primarily austenitic structure with approximately 
$5-10$ vol.\% of ferritic phase. Ferrite arises due to the high $\mathrm{Cr}_{\mathrm{eq}} / \mathrm{Ni}_{\mathrm{eq}}$ ratio (1.82, Table 3), but post-building heat treatment at $1150{ }^{\circ} \mathrm{C}$ allows it to decrease significantly (Figure 9). In [60], laser engineering net shaping AM was utilized for building billets of AISI 316L steel. Steel had austenitic structure with intercellular ferritic and $\sigma-(\mathrm{FeCr})$ phases on subgrain boundaries (Figure 10). Saeidi et al. [51,61] used powder-feed laser melting AM for producing billets of AISI 316L billets with coarse-grained columnar austenitic structure (average grain size was 10-100 $\mu \mathrm{m}$ ) with a small amount of ferritic phase and $\mathrm{Cr}$-containing silicate nano-inclusions in the austenite lattice. Austenitic grains had subgrain structure with subgrain size about $0.5 \mu \mathrm{m}$ and subgrain boundaries enriched with Mo.
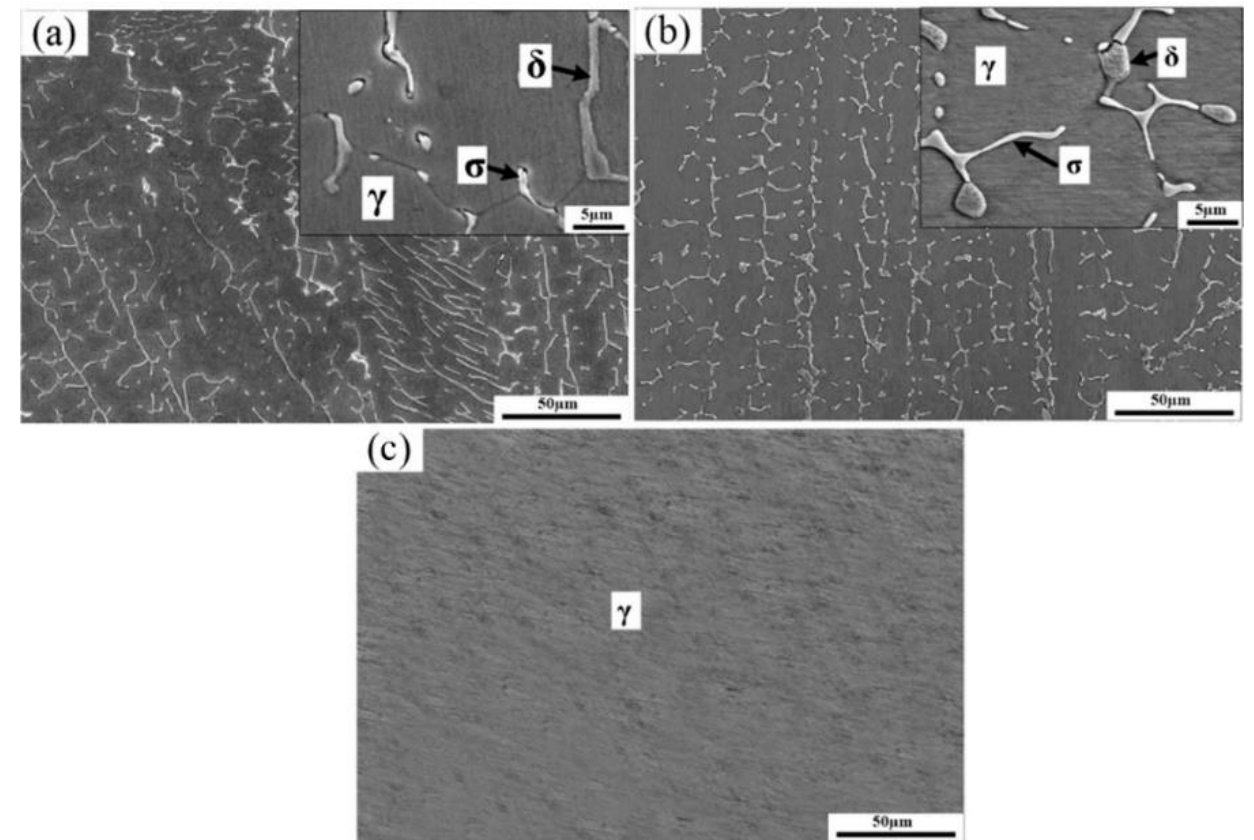

Figure 8. Microstructures of as-deposited and heat-treated GMA-AM 316L: (a) as-deposited, (b) solid solution treatment $1000^{\circ} \mathrm{C} / 1 \mathrm{~h}$, water quenching (WQ), and (c) $1200{ }^{\circ} \mathrm{C} / 4 \mathrm{~h}$, WQ. Reprinted with permission from [59], Copyright 2018 Elsevier.
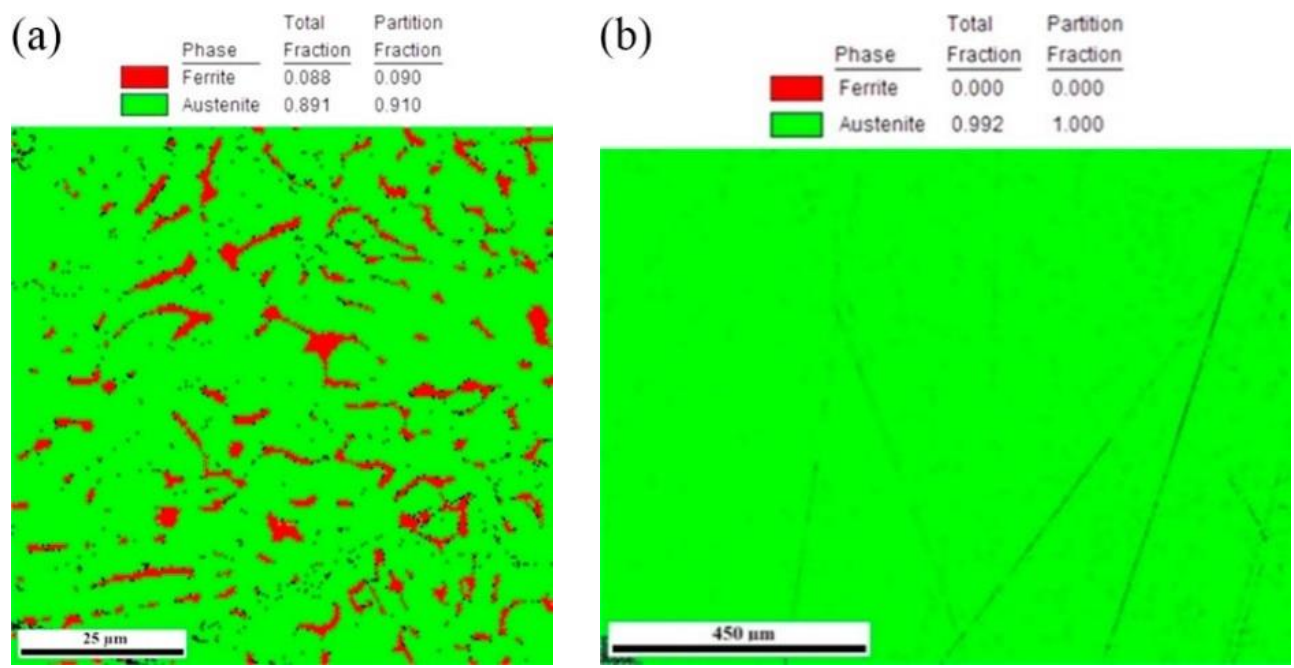

Figure 9. EBSD phase fraction map of a selected area in (a) the middle region of a single-built sample and in (b) the bottom region of a single-built sample after heat treatment. Reprinted with permission from Ref. [21]. Copyright 2015 Elsevier. 
(a)

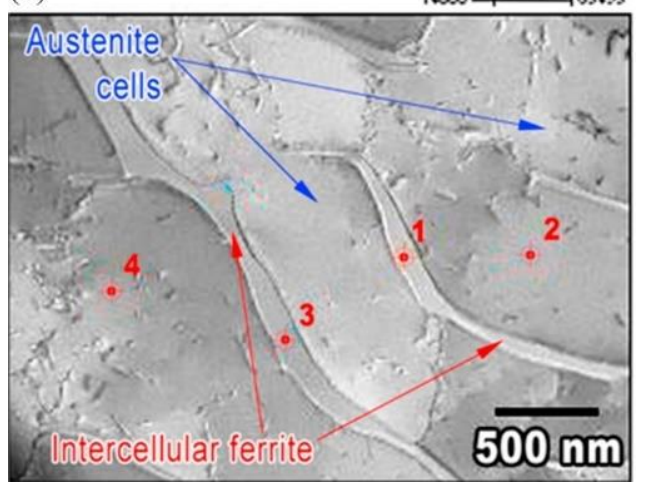

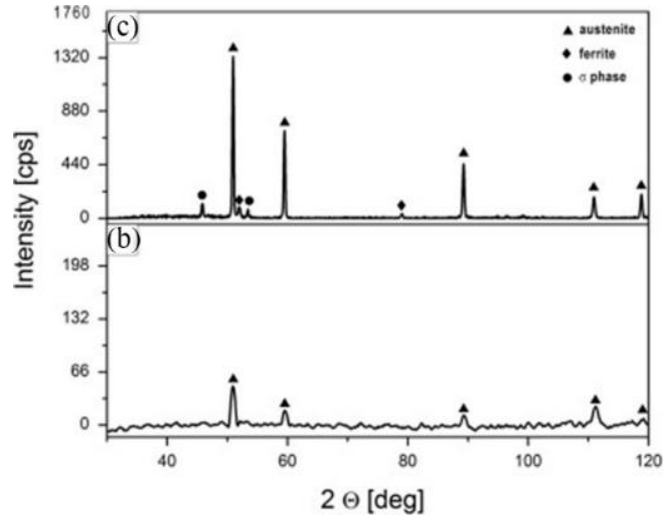

Figure 10. Microstructure of the $316 \mathrm{~L}$ stainless steel samples produced using (a) the laser ingineered net shaping technique and (b) X-ray diffraction patterns of the $316 \mathrm{~L}$ stainless steel powder, and (c) sample obtained using the LENS technique. Reprinted with permission from [60], Copyright 2016 Elsevier.

In some research groups, near single phase ( $\delta$-ferrite and $\sigma$-phase free) steel billets have been obtained. Barkia et al. [19] utilized a powder-feed direct laser deposition technique for producing the billets of AISI 316L steel. Powder of AISI 316L austenitic stainless steel (Fe-17.7Cr-12.6Ni-2.33Mo-0.58Si-0.29Mn-0.15Co-0.026S-0.026V-0.024Cu-0.01P0.016C, wt.\%, $\left.\mathrm{Cr}_{\mathrm{eq}} / \mathrm{Ni}_{\mathrm{eq}}=1.58\right)$ with particle sizes of $45-106 \mu \mathrm{m}$ was used as the raw material. The produced billets with the $99.7 \%$ density had no voids and pores, and they possessed fully austenitic structure with nanosized Si-containing oxides and metal-reached precipitates located in the grain boundaries (Figure 11). Ganesh et al. [62,63] obtained fully austenitic billets of AISI316L stainless steel using powder-feed laser rapid manufacturing. A similar result was obtained by Zhong et al. [20], who used the powder feed EBAM for fabrication of Fe-17.4Cr-12.4Ni-2.5Mo-1.5Mn-0.53Si-0.06N-0.053Cu-0.53Si-0.02C (wt.\%) steel. Using laser powder bed fusion AM technique and SLM, Zhang [56] and Bahl et al. [64] obtained fully austenitic structure in AISI 316L stainless steel despite the FA solidification mode $\left(\mathrm{Cr}_{\mathrm{eq}} / \mathrm{Ni}_{\mathrm{eq}}=1.53\right)$.
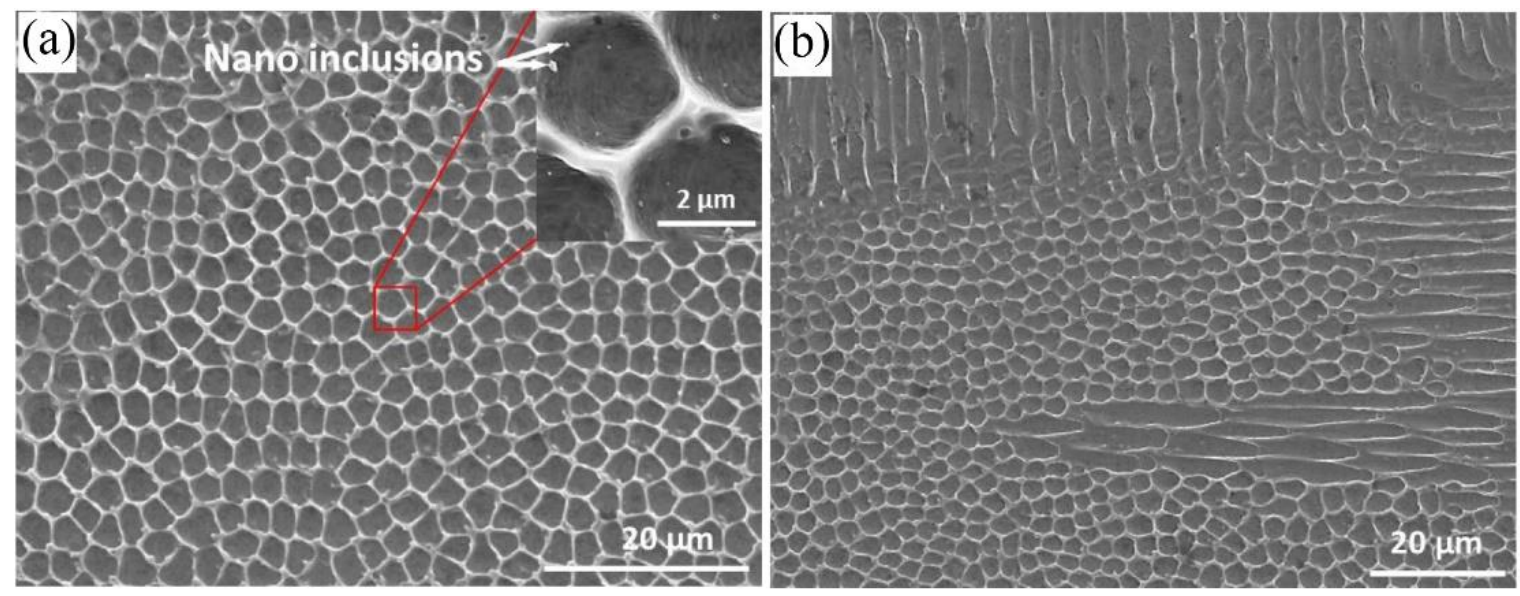

Figure 11. SEM images illustrating the typical cellular microstructure of powder-feed direct laser deposited AISI 316L steel: (a) equiaxed cells; and (b) evidence of elongated cells at the melt pool boundaries. Reprinted with permission from [19], Copyright 2020 Elsevier.

Several studies were focused on the effect of AM-processing parameters on the phase composition of 316-type steels. In [14] the authors showed that scanning strategy during the SLM process does not affect phase composition of AM AISI 316L steel, which had austenitic structure. 
Wen et al. [55] has shown that in WAAM-fabricated AISI 316LN steel (Fe-18.39Cr$12.5 \mathrm{Ni}-2.25 \mathrm{Mo}-1.69 \mathrm{Mn}-0.81 \mathrm{Si}-0.02 \mathrm{C}-0.015 \mathrm{~S}-0.015 \mathrm{P}-0.013 \mathrm{~N}$, wt.\%), the volume content of $\delta$-ferrite (17.3-17.7 vol.\%) does not depend on the linear heat input (LHI) value, which influences the distance between austenitic dendrites only. This distance increases from 18 to $23 \mu \mathrm{m}$ with the increase in LHI from 219 to $590 \mathrm{~J} / \mathrm{mm}$ due to the decrease in cooling rate and the fact that the cooling time does not last long enough for large austenitic dendrites formation (Figure 12).

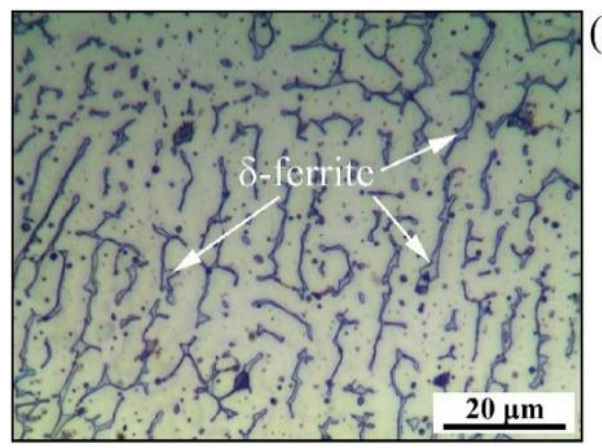

(a)

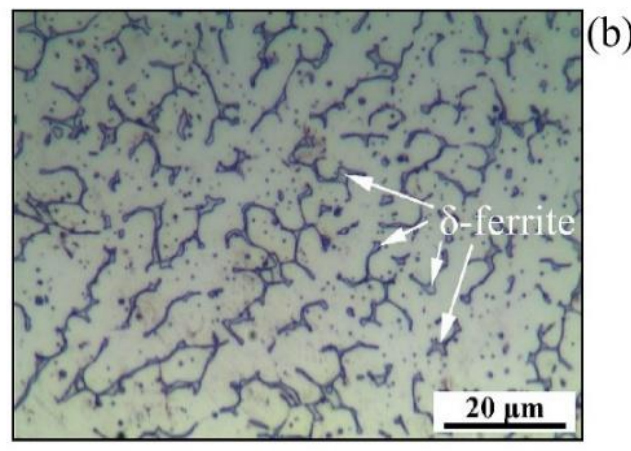

Figure 12. Microstructure of the WAAM 316L stainless steel under (a) high heat input and (b) low heat input. Reprinted with permission from [55], Copyright 2020 Elsevier.

Yang et al. [28] investigated the influence of arc current on structure and corrosion resistance of WAAM-fabricated AISI 316 L steel (Fe-18.42Cr-12.28Ni-2.46Mo-1.55Mn-0.78Si$\left.0.02 \mathrm{C}, \mathrm{wt} . \%, \mathrm{Cr}_{\mathrm{eq}} / \mathrm{Ni}_{\mathrm{eq}}=1.5\right)$. They pointed out that for the arc current changing from 140 to $180 \mathrm{~A}$, the decrease in cooling rate provides the reduced volume fraction of ferrite. Morphology of ferritic phase also changes from lathy to skeleton one and $\sigma$-phase forms with increase in arc current. Kurzynowski et al. [14] have shown that due to high cooling rates in the SLM process the primary austenite formation dominates despite FA solidification mode according to the chemical composition of the powder ( $316 \mathrm{~L}$ steel, $\mathrm{Cr}_{\mathrm{eq}} / \mathrm{Ni}_{\mathrm{eq}}=1.42$ ). Non-equilibrium ferritic phase is formed in intercellular austenitic regions, and volume content of $\delta$-phase decreases with the increase in laser power (Figure 13).
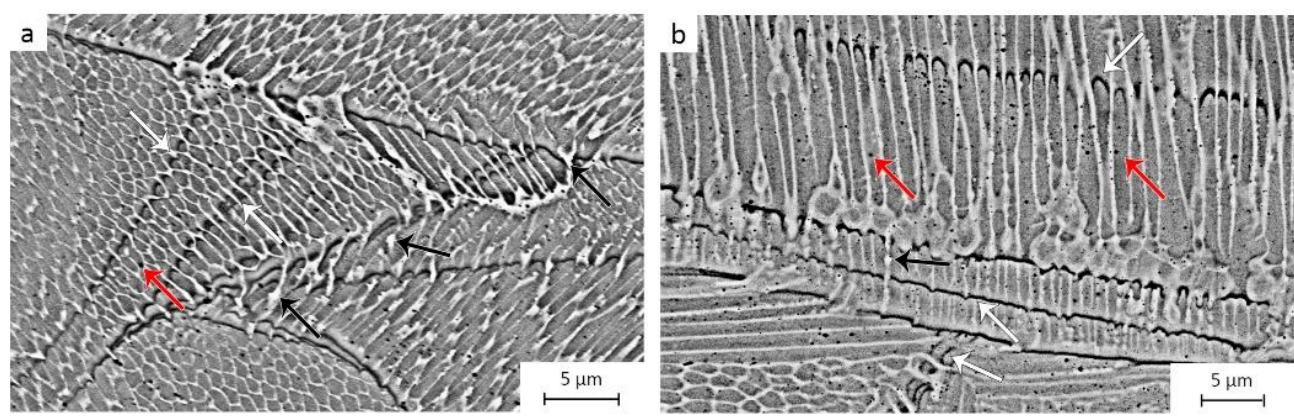

Figure 13. Backscattered SEM images of as-built microstructures showing cellular substructure in xz plane of specimens: (a) Laser power $100 \mathrm{~W}$ and (b) Laser power $200 \mathrm{~W}$. White arrows indicate segregation traces at cells tips (solute banding lines), black arrows-eutectic $\delta$-ferrite, and red arrowsnanoinclusions. Reprinted with permission from [14], Copyright 2018 Elsevier.

Strength properties of the AM-produced specimens of type 316 steel are comparable or even better than those of wrought AISI 316L steel (Table 4). Produced steel $[14,21,26,60]$ had high strength properties but lower ductility in comparison with conventionally produced counterparts. Intermetallic $\sigma$-phase, ferritic phase, Mo and $\mathrm{Cr}$ segregation in intercellular boundaries all increase microhardness and ultimate tensile strength of AM specimens, but reduce corrosion resistance [59] and ductility [14,26]. Ferrite and $\sigma$-phase both disimproves 
the corrosion resistance of AM-fabricated AISI 316LN steel due to depletion of austenitic phase by $\mathrm{Cr}$ and Mo atoms, which segregate in the ferritic phase $[28,55]$.

Table 4. Comparison of mechanical properties of some AM AISI 316L stainless steels. The compositions are given in wt.\%. Data are adapted from $[14,21,26,60,64-66]$.

\begin{tabular}{|c|c|c|c|}
\hline Method of Manufacture & Yield Strength, MPa & Ultimate Tensile Strength, MPa & Elongation, $\%$ \\
\hline \multicolumn{4}{|c|}{ Conventionally produced AISI 316 SS } \\
\hline AISI 316L rolled sheet [14] & $220-270$ * & $520-680 *$ & $40-45$ * \\
\hline Cast [21] & 262 & 552 & 55 \\
\hline Wrought (cold finished) [21] & $255-310$ & $525-623$ & 30 \\
\hline $316 \mathrm{~L}$ anneal rod $[65]$ & 241 & 586 & 50 \\
\hline AISI 316L annealed [66] & $341-368^{* *}$ & $973-1083^{* *}$ & $59-73 * *$ \\
\hline \multicolumn{4}{|c|}{ AISI 316 SS fabricated with AM methods } \\
\hline $\begin{array}{c}\text { WAAM, AISI 316L } \\
\text { (Fe-18.74Cr-11.82Ni-2.67Mo-1.55Mn- } \\
\text { 0.56Si-0.17Cu-0.03P-0.0014C) [26] }\end{array}$ & 235 & 533 & 48 \\
\hline SLM, AISI316L [14] & 517 & 687 & 32 \\
\hline SLM, AISI316L [64] & $480-550 *$ & $565-675 *$ & $44-66 *$ \\
\hline DLD, AISI 316L & & & \\
\hline $\begin{array}{c}\text { (Fe-19.95Cr-10.87Ni-2.45Mo-1.41Mn- } \\
\text { 0.61Si-0.042C-0.025P-0.011S) [21] }\end{array}$ & $405-415$ * & $620-660^{*}$ & $32-40^{*}$ \\
\hline $\begin{array}{c}\text { LENS, AISI 316L } \\
(\text { Fe-20Cr-11.8Ni-2.41Mo-0.91Mn- }<0.03 \mathrm{C}, \\
\text { wt.\%) [60] }\end{array}$ & $479-576^{*}$ & $703-776^{*}$ & 33 \\
\hline
\end{tabular}

* Intervals indicate the variation of the mechanical properties due to the anisotropy of the microstructure. ${ }^{* *}$ Depending on strain rate.

Analysis of $\mathrm{Cr}_{\mathrm{eq}} / \mathrm{Ni}_{\mathrm{eq}}$ ratio for different 316-type steel compositions and phase compositions of the AM-fabricated materials shows that independently on solidification mode (in particular, FA mode in [19] and AF one in [20]), powder-feed technologies allow the obtaining of ferrite-free AISI 316L austenitic stainless steel. Moreover, rather simple postprocessing heat treatment allows the elimination of undesirable phases and the obtaining of single-phase austenitic structure in AM-billets, in which the heterophase structure forms in AM-fabrication. But existing data are still not enough for comprehensive analysis of the effect of AM-producing methods and regimes on phase composition and mechanical properties of the 316-type steel.

\section{Conclusions and Possible Trends of Investigations}

A comprehensive analysis on the influence of AM techniques and process parameters on the microstructure and mechanical properties of additively manufactured austenitic stainless steels of 300-series was done with the focus on phase composition of the AMproducts. During AM fabrication, the final phase composition of the steels depends on a large number of different factors, including: (1) chemical composition of the steel, which defines the solidification mode; and (2) AM technology and AM process parameters, which are responsible for thermal history of the AM billets. The combination of these factors governs the properties of steel components, which could have either fully austenitic or heterophase structure (austenite, ferrite, $\sigma$-phase, and segregations of alloying elements on interphase boundaries).

The goal in AM-producing of the CrNi austenitic stainless steels (type AISI 304, 308 and 316) is obtaining near single-phase austenitic structure possessing strength and ductility similar to those obtained in conventional metallurgy. Using powder bed AM methods, the authors have obtained fully austenitic structures using powder bed AM methods even for the compositions with high $\mathrm{Cr}_{\mathrm{eq}} / \mathrm{Ni}_{\mathrm{eq}}$ ratios, corresponding to $\mathrm{FA}$ or even $\mathrm{F}$ solidification mode $[11,14,56]$. Contrarily, in wire-feed electron beam or arc AM, the large volume fraction of $\delta$-ferrite phase (up to $20 \%$ ) is formed (see, for instance, $[7,8,26,55]$ ). Despite this fact, the choice of specific method of AM production does not guarantee the proper phases. Presence of $\delta$-ferrite and $\sigma$-phase is determined by both the chemical composition 
of raw materials and fabrication method, as well as by dimensions of the printed part and parameters of the AM process (cooling rate, heat input, deposition rate, etc.).

The direct comparison of the mechanical properties of the steel products fabricated in different AM methods shows that $\delta$ - and $\sigma$-phases could have both positive and negative effects. Ferritic dendrites, small intermetallic particles, and segregations of alloying elements (such as $\mathrm{Cr}, \mathrm{Mo}$, $\mathrm{Si}$, etc.) all increase strength characteristics of AM-fabricated steels (Tables 2 and 4 ) but decreases ductility and corrosion resistance relative to the conventionally produced counterparts. So, depending on the target characteristics of additively produced parts these factors should be considered.

Possible promising trends of future investigations in the field of additive manufacturing of chromium-nickel austenitic stainless steels could be focused on searching for the ways of obtaining fully austenitic homogeneous isotropic structures. In particular, the problem could be solved in different ways:

- by choosing the appropriate chemical composition of the raw material with low $\mathrm{Cr}_{\text {eq }} / \mathrm{Ni}_{\text {eq }}$ ratio, adding the nickel powder/wire or other austenite-forming elements (manganese, nitrogen, etc.) to the raw material;

- $\quad$ by optimization of parameters of AM process; and

- $\quad$ by development of the post-processing treatments.

Author Contributions: Conceptualization, E.A.; Investigation, S.A.; Supervision, E.A.; Writingoriginal draft, S.A.; Writing-review and editing, E.A. Both authors have read and agreed to the published version of the manuscript.

Funding: The work was performed according to the government research assignment for ISPMS SB RAS, project FWRW-2019-0030.

Institutional Review Board Statement: Not applicable.

Informed Consent Statement: Not applicable.

Data Availability Statement: The data presented in this study are available on request from the corresponding authors of the articles from the reference list.

Conflicts of Interest: The authors declare no conflict of interest.

\section{References}

1. Ding, D.; Pan, Z.; Cuiuri, D.; Li, H. Wire-feed additive manufacturing of metal components: Technologies, developments and future interests. Int. J. Adv. Manuf. Technol. 2015, 81, 465-481. [CrossRef]

2. DebRoy, T.; Wei, H.L.; Zuback, J.S.; Mukherjee, T.; Elmer, J.W.; Milewski, J.O.; Beese, A.M.; Wilson-Heid, A.; De, A.; Zhang, W. Additive manufacturing of metallic components-Process, structure and properties. Progr. Mater. Sci. 2018, 92, 112-224. [CrossRef]

3. Calleja-Ochoa, A.; Gonzalez-Barrio, H.; López de Lacalle, N.; Martínez, S.; Albizuri, J.; Lamikiz, A. A new approach in the design of microstructured ultrulight components to achieve maximum functional performance. Materials 2021, 14, 1588. [CrossRef]

4. Li, N.; Huang, S.; Zhang, G.; Qin, R.; Liu, W.; Xiong, H.; Shi, G.; Blackburn, J. Progress in additive manufacturing on new materials: A review. J. Mater. Sci. Technol. 2019, 35, 242-269. [CrossRef]

5. Bajaj, P.; Hariharan, A.; Kini, A.; Kürnsteiner, P.; Raabe, D.; Jägle, E.A. Steels in additive manufacturing: A review of their microstructure and properties. Mater. Sci. Eng. A 2020, 772, 138633. [CrossRef]

6. Frazier, W.E. Metal additive manufacturing: A review. J. Mater. Eng. Perform. 2014, 23, 1917-1928. [CrossRef]

7. Astafurova, E.G.; Panchenko, M.Y.; Moskvina, V.A.; Maier, G.G.; Astafurov, S.V.; Melnikov, E.V.; Fortuna, A.S.; Reunova, K.A.; Rubtsov, V.E.; Kolubaev, E.A. Microstructure and grain growth inhomogeneity in austenitic steel produced by wire-feed electron beam melting: The effect of post-building solid-solution treatment. J. Mater. Sci. 2020, 55, 9211-9224. [CrossRef]

8. Tarasov, S.Y.; Filippov, A.V.; Savchenko, N.L.; Fortuna, S.V.; Rubtsov, V.E.; Kolubaev, E.A.; Psakhie, S.G. Effect of heat input on phase content, crystalline lattice parameter, and residual strain in wire-feed electron beam additive manufactured 304 stainless steel. Int. J. Adv. Manuf. Technol. 2018, 99, 2353-2363. [CrossRef]

9. Lo, K.H.; Shek, C.H.; Lai, J.K.L. Recent developments in stainless steels. Mat. Sci. Eng. R 2009, 65, 39-104. [CrossRef]

10. Bhadeshia, H.; Honeykombe, R. Steels: Microstructure and Properties; Elsevier: Amsterdam, The Netherlands, 2006.

11. Yu, H.; Yang, J.; Yin, J.; Wang, Z.; Zeng, X. Comparison on mechanical anisotropies of selective laser melted Ti-6Al-4V alloy and 304 stainless steel. Mater. Sci. Eng. A 2017, 695, 92-100. [CrossRef] 
12. Hou, J.; Chen, W.; Chen, Z.; Zhang, K.; Huang, A. Microstructure, tensile properties and mechanical anisotropy of selective laser melted 304L stainless steel. J. Mater. Sci. Technol. 2020, 48, 63-71. [CrossRef]

13. Zhang, Y.; Huang, W. Comparisons of 304 austenitic stainless steel manufactured by laser metal deposition and selective laser melting. J. Manuf. Proc. 2020, 57, 324-333. [CrossRef]

14. Kurzynowski, T.; Gruber, K.; Stopyra, W.; Kuźnicka, B.; Chlebus, E. Correlation between process parameters, microstructure and properties of $316 \mathrm{~L}$ stainless steel processed by selective laser melting. Mater. Sci. Eng. A 2018, 718, 64-73. [CrossRef]

15. Salman, O.O.; Brenne, F.; Niendorf, T.; Eckert, J.; Prashanth, K.G.; He, T.; Scudino, S. Impact of the scanning strategy on the mechanical behavior of 316L steel synthesized by selective laser melting. J. Manuf. Process. 2019, 45, 255-261. [CrossRef]

16. Wang, Z.; Palmer, T.A.; Beese, A.M. Effect of processing parameters on microstructure and tensile properties of austenitic stainless steel 304L made by directed energy deposition additive manufacturing. Acta. Mater. 2016, 110, 226-235. [CrossRef]

17. Brown, D.W.; Adams, D.P.; Balogh, L.; Carpenter, J.S.; Clausen, B.; King, G.; Reedlunn, B.; Palmer, T.A.; Maguire, M.C.; Vogel, S.C. In situ neutron diffraction study of the influence of microstructure on the mechanical response of additively manufactured $304 \mathrm{~L}$ stainless steel. Metallurg. Mater. Trans. A 2017, 48, 6055-6069. [CrossRef]

18. Melia, M.A.; Nguyen, H.-D.A.; Rodelas, J.M.; Schindelholz, E.J. Corrosion properties of 304L stainless steel made by directed energy deposition additive manufacturing. Corros. Resist. 2019, 152, 20-30. [CrossRef]

19. Barkia, B.; Aubry, P.; Haghi-Ashtiani, P.; Auger, T.; Gosmain, L. On the origin of the high tensile strength and ductility of additively manufactured 316L stainless steel: Multiscale investigation. J. Mater. Sci. Technol. 2020, 41, 209-218. [CrossRef]

20. Zhong, Y.; Rännar, L.-E.; Liu, L.; Koptyug, A.; Wikman, S.; Olsen, J.; Cui, D.; Shen, Z. Additive manufacturing of 316L stainless steel by electron beam melting for nuclear fusion applications. J. Nucl. Mater. 2017, 486, 234-245. [CrossRef]

21. Yadollahi, A.; Shamsaei, N.; Thompson, S.M.; Seely, D.W. Effects of process time interval and heat treatment on the mechanical and microstructural properties of direct laser deposited 316L stainless steel. Mater. Sci. Eng. A 2015, 644, 171-183. [CrossRef]

22. Abioye, T.E.; Medrano-Tellez, A.; Farayibi, P.K.; Oke, P.K. Laser metal deposition of multi-track walls of 308LSi stainless steel. Mater. Manuf. Process. 2017, 32, 1660-1666. [CrossRef]

23. Gordon, J.V.; Haden, C.V.; Nied, H.F.; Vinci, R.P.; Harlow, D.G. Fatigue crack growth anisotropy, texture and residual stress in austenitic steel made by wire and arc additive manufacturing. Mater. Sci. Eng. A 2018, 724, 431-438. [CrossRef]

24. Le, V.T.; Mai, D.S.; Hoang, Q.H. Effects of cooling conditions on the shape, microstructures, and material properties of SS308L thin walls built by wire arc additive manufacturing. Mater. Lett. 2020, 280, 128580. [CrossRef]

25. Li, Y.; Luo, Y.; Li, J.; Song, D.; Xu, B.; Chen, X. Ferrite formation and its effect on deformation mechanism of wire arc additive manufactured 308 L stainless steel. J. Nuclear Mater. 2021, 550, 152933. [CrossRef]

26. Chen, X.; Li, J.; Cheng, X.; He, B.; Wang, H.; Huang, Z. Microstructure and mechanical properties of the austenitic stainless steel 316L fabricated by gas metal arc additive manufacturing. Mater. Sci. Eng. A 2017, 703, 567-577. [CrossRef]

27. Wang, L.; Xue, J.; Wang, Q. Correlation between arc mode, microstructure, and mechanical properties during wire arc additive manufacturing of 316L stainless steel. Mater. Sci. Eng. A 2019, 751, 183-190. [CrossRef]

28. Yang, K.; Wang, Q.; Qu, Y.; Jiang, Y.; Bao, Y. Microstructure and corrosion resistance of arc additive manufactured 316L stainless steel. J. Wuhan Univ. Technol. Mater. Sci. Ed. 2020, 35, 930-936. [CrossRef]

29. Panchenko, M.Y.; Maier, G.G.; Moskvina, V.A.; Melnikov, E.V.; Astafurov, S.V.; Rubtsov, V.E.; Kolubaev, E.A.; Astafurova, E.G. Microstructural inhomogeneity of phase composition and grain structure in electron beam wire-feed additive manufactured AISI 304 stainless steel. AIP Conf. Proc. 2019, 2167, 020261.

30. Moskvina, V.A.; Panchenko, M.Y.; Astafurov, S.V.; Maier, G.G.; Melnikov, E.V.; Rubtsov, V.E.; Kolubaev, E.A.; Astafurova, E.G. A comparative study of the macroscopical and microscopical fracture mechanisms in cast and additively manufactured austenitic stainless steels. AIP Conf. Proc. 2019, 2167, 020234.

31. Kruth, J.-P.; Levy, G.; Klocke, F.; Childs, T.H.C. Consolidation phenomena in laser and powder-bed based layered manufacturing. CIRP Ann. 2007, 56, 730-759. [CrossRef]

32. Suuatala, N.; Takalo, T.; Moisio, T. The relationship between solidification and microstructure in austenitic and austenitic-ferritic stainless steel welds. Metall. Trans. A 1979, 10, 512-514. [CrossRef]

33. Kim, Y.H.; Kim, D.G.; Sung, J.H.; Kim, I.S.; Ko, D.E.; Kang, N.H.; Hong, H.U.; Park, J.H.; Lee, H.W. Influences of Cr/Ni equivalent ratios of filler wires on pitting corrosion and ductility-dip cracking of AISI 3161 weld metals. Met. Mater. Int. 2011, 17, 151-155. [CrossRef]

34. Jacob, G. Prediction of solidification phases in Cr-Ni stainless steel alloys manufactured by laser based powder bed fusion process. NIST. Adv. Manuf. Ser. 2018, 100-114, 1-38. [CrossRef]

35. Olson, D.L. Prediction of austenitic weld metal microstructure and properties. Weld. Res. Suppl. 1985, 64, s281-s295.

36. Sindo, K. Welding Metallurgy, 2nd ed.; Willey: New York, NY, USA, 2003.

37. Guan, K.; Wang, Z.; Gao, M.; Li, X.; Zeng, X. Effects of processing parameters on tensile properties of selective laser melted 304 stainless steel. Mater. Des. 2013, 50, 581-586. [CrossRef]

38. Saha, S.; Mukherjee, M.; Pal, T.K. Microstructure, texture, and mechanical property analysis of gas metal arc welded AISI 304 austenitic stainless steel. J. Mater. Eng. Perfom. 2015, 24, 1125-1139. [CrossRef]

39. Olson, G.B.; Cohen, M. A mechanism for the strain-induced nucleation of martensitic transformations. J. Less Common Met. 1972, 28, 107-118. [CrossRef] 
40. Lecroisey, F.; Pineau, A. Martensitic transformations induced by plastic deformation in the Fe-Ni-Cr-C system. Metallurg. Trans. 1972, 3, 387-396. [CrossRef]

41. Shen, Y.F.; Li, X.X.; Sun, X.; Wang, Y.D.; Zuo, L. Twinning and martensite in a 304 austenitic stainless steel. Mater. Sci. Eng. A 2012, 552, 514-522. [CrossRef]

42. Beese, A.M.; Mohr, D. Effect of stress triaxiality and Lode angle on the kinetics of strain-induced austenite-to-martensite transformation. Acta. Mater. 2011, 59, 2589-2600. [CrossRef]

43. Le, V.T.; Mai, D.S.; Doan, T.K.; Paris, H. Wire and arc additive manufacturing of 308L stainless steel components: Optimization of processing parameters and material properties. Eng. Sci. Technol. Int. J 2021, in press.

44. Tarasov, S.Y.; Filippov, A.V.; Shamarin, N.N.; Fortuna, S.V.; Maier, G.G.; Kolubaev, E.A. Microstructural evolution and chemical corrosion of electron beam wire-feed additively manufactured AISI 304 stainless steel. J. Alloy. Comp. 2019, 803, 364-370. [CrossRef]

45. Zhao, J.; Hou, J.; Chen, L.; Dai, B.; Xiong, X.; Tan, L.; Xhang, K.; Huang, A. Evaluating impact performance of a selective laser melted 304L stainless steel with weak texture. Mater. Today Commun. 2020, 25, 101299. [CrossRef]

46. Li, M.; Lu, T.; Dai, J.; Jia, X.; Gu, X.; Dai, T. Microstructure and mechanical properties of 308L stainless steel fabricated by laminar plasma additive manufacturing. Mater. Sci. Eng. A 2020, 770, 138523. [CrossRef]

47. Panchenko, M.Y.; Moskvina, V.A.; Astafurov, S.V.; Maier, G.G.; Melnikov, E.V.; Rubtsov, V.E.; Kolubaev, E.A.; Astafurova, E.G. On the influence of post-built heat treatment on strength and ductility of AISI 304 steel produced by electron-beam additive technology. AIP Conf. Proc. 2019, 2167, 020262.

48. Melnikov, E.V.; Astafurova, E.G.; Astafurov, S.V.; Panchenko, M.Y.; Moskvina, V.A.; Maier, G.G.; Astafurov, S.V.; Fortuna, A.S.; Reunova, K.A.; Rubtsov, V.E.; et al. Anisotropy of the tensile properties in austenitic stainless steel obtained by wire-feed electron beam additive growth. Lett. Mater. 2019, 9, 460-464. [CrossRef]

49. Fu, J.W.; Yang, Y.S. Origin of the lathy ferrite in AISI 304 stainless steel during directional solidification. J. Alloy. Comp. 2013, 580, 191-194. [CrossRef]

50. Brown, D.W.; Adams, D.P.; Balogh, L.; Carpenter, J.S.; Clausen, B.; Livescu, V.; Martinez, R.M.; Morrow, B.M.; Palmer, T.A.; Pokharel, R.; et al. Using in situ neutron diffraction to isolate specific features of additively manufactured microstructures in 304L stainless steel and identify their effects on macroscopic strength. Metallurg. Mater. Trans. A. 2019, 50, 3399-3413. [CrossRef]

51. Saeidi, K.; Gao, X.; Zhong, Y.; Shen, Z.J. Hardened austenite steel with columnar sub-grain structure formed by laser melting. Mater. Sci. Eng. A 2015, 625, 221-229. [CrossRef]

52. Godec, M.; Zaefferer, S.; Podgornik, B.; Šinko, M.; Tchernychova, E. Quantitative multiscale correlative microstructure analysis of additive manufacturing of stainless steel 316L processed by selective laser melting. Mater. Charact. 2020, 160, 110074. [CrossRef]

53. Lima, M.S.F.; Sankaré, S. Microstructure and mechanical behavior of laser additive manufactured AISI 316 stainless steel stringers. Mater. Des. 2014, 55, 526-532. [CrossRef]

54. Pinto, F.C.; Souza Filho, I.R.; Sandim, M.J.R.; Sandim, H.R.Z. Defects in parts manufactured by selective laser melting caused by $\delta$-ferrite in reused 316L steel powder feedstock. Addit. Manuf. 2020, 31, 100979. [CrossRef]

55. Wen, D.; Long, P.; Li, J.; Huang, L.; Zheng, Z. Effects of linear heat input on microstructure and corrosion behavior of an austenitic stainless steel processed by wire arc additive manufacturing. Vacuum 2020, 173, 109131. [CrossRef]

56. Zhang, X.; Kenesei, P.; Park, J.-S.; Almer, J.; Li, M. In situ high-energy X-ray study of deformation mechanisms in additively manufactured 316L stainless steel. J. Nucl. Mater. 2021, 549, 152874. [CrossRef]

57. Chen, J.; Wei, H.; Zhang, X.; Peng, Y.; Kong, J.; Wang, K. Flow behavior and microstructure evolution during dynamic deformation of $316 \mathrm{~L}$ stainless steel fabricated by wire and arc additive manufacturing. Mater. Des. 2021, 198, 109325. [CrossRef]

58. Chen, J.; Wei, H.; Bao, K.; Xhang, X.; Cao, Y.; Peng, Y.; Kong, J.; Wang, K. Dynamic mechanical properties of 316L stainless steel fabricated by an additive manufacturing process. J. Mater. Res. Technol. 2021, 11, 170-179. [CrossRef]

59. Chen, X.; Li, J.; Cheng, X.; Wang, H.; Huang, Z. Effect of heat treatment on microstructure, mechanical and corrosion properties of austenitic stainless steel 316L using arc additive manufacturing. Mater. Sci. Eng. A 2018, 715, 307-314. [CrossRef]

60. Zietala, M.; Durejko, T.; Polański, M.; Kunce, I.; Płociński, T.; Zieliński, W.; Łazińska, M.; Stepniowski, W.; Czujko, T.; Kurzydłowski, K.J.; et al. The microstructure, mechanical properties and corrosion resistance of $316 \mathrm{~L}$ stainless steel fabricated using laser engineered net shaping. Mater. Sci. Eng. A 2016, 677, 1-10. [CrossRef]

61. Saeidi, K.; Gao, X.; Lofaj, F.; Kvetková, L.; Shen, Z.J. Transformation of austenite to duplex austenite-ferrite assembly in annealed stainless steel 316L consolidated by laser melting. J. Alloy. Comp. 2015, 633, 463-469. [CrossRef]

62. Ganesh, P.; Giri, R.; Kaul, R.; Ram Sankar, P.; Tiwari, P.; Atulkar, A.; Porwal, R.K.; Dayal, R.K.; Kukreja, L.M. Studies on pitting corrosion and sensitization in laser rapid manufactured specimens of type 316L stainless steel. Mater. Des. 2012, 39, 509-521. [CrossRef]

63. Ganesh, P.; Kaul, R.; Sasikala, G.; Kumar, H.; Venugopal, S.; Tiwari, P.; Rai, S.; Prasad, R.C.; Kukreja, L.M. Fatigue crack propagation and fracture toughness of laser rapid manufactured structures of AISI 316L stainless steel. Metallogr. Microstruct. Anal. 2014, 3, 36-45. [CrossRef]

64. Bahl, S.; Mishra, S.; Yaza, K.U.; Kola, I.R.; Chatterjee, K.; Suwas, S. Non-equilibrium microstructure, crystallographic texture and morphological texture synergistically result in unusual mechanical properties of 3D printed stainless steel. Addit. Manuf. 2019, 28, 65-77. [CrossRef] 
65. Zhang, K.; Wang, S.; Liu, W.; Shang, X. Characterization of stainless steel parts by laser metal deposition shaping. Mater. Des. 2014, 55, 104-119. [CrossRef]

66. Astafurov, S.V.; Maier, G.G.; Melnikov, E.V.; Moskvina, V.A.; Panchenko, M.Y.; Astafurova, E.G. The strain-rate dependence of the Hall-Petch effect in two austenitic stainless steels with different stacking fault energies. Mater. Sci. Eng. A 2019, 756, 365-372. [CrossRef] 